\title{
Roman Deiksler
}

(Adam Mickiewicz University in Poznań, Poland)

https://orcid.org/0000-0002-5645-7240

E-mail: roman.deiksler@amu.edu.pl

\section{The Wives of Felix, the Procurator of Judaea}

\section{Żony Feliksa, prokuratora Judei}

\begin{abstract}
The article attempts at presenting the wives of Felix - a procurator of Judaea from 52 to 58/60 A.D. The governor is supposed to have had relationships with three women, two of whom are better known than the third. The author strives for solving the problem of kinship between the first wife - Drusilla of Mauretania - and Cleopatra VII, which is mentioned by Tacitus. Some researchers, however, have discredited the statement of the Roman historian that Drusilla would have been the granddaughter of the Egyptian queen. It was accepted by most historians and has been repeated in the following studies concerning Drusilla of Mauretania. Nevertheless, the renewed analysis of the matter indicates that it was Tacitus who was right and that Drusilla was the granddaughter of Cleopatra indeed. The second part of the article presents the second wife of Felix, who was the daughter of Agrippa I and is supposed to have started her relationship with the procurator of Judaea during his stay in the province.
\end{abstract}

Key words: Judea, Jews, Roman provinces in the 1st century, Roman governors, Roman administration, Prefects and procurators of Judea, Drusilla of Mauretania

\begin{tabular}{|l|l|l|l|}
\hline \multicolumn{2}{|l|}{ PUBLICATION INFO } \\
\hline
\end{tabular}


Felix was a procurator of Judaea from $52^{1}$ to $58 / 60$ A.D. ${ }^{2}$ The period of his service cannot be called a peaceful one. As the procurator, he can be held responsible for the intensification of riots that took place in the province - to kill Jonathan, the High Priest, he used the help of the Sicarii that initiated their activity ${ }^{3}$. He is remembered by Christians as the first judge of Saul of Tarsus. His brother, Pallas, fulfilled an important function in the Roman Empire ${ }^{4}$. Besides, Felix led an interesting private life. His partners attract special attention. According to Suetonius, Felix is said to have had relationships with three women from royal families: Drusilla of Mauretania, Drusilla, the daughter of Agrippa I, and with another further unnamed woman ${ }^{5}$.

1 He replaced Ventidius Cumanus in this office. Before he became a procurator of Judaea, Felix might have served as a commander in Samaria and a part of Judaea (see: Die Annalen des Tacitus, vol. 2, books 11-16, ed. A.A. Draeger, Leipzig 1869 [hereinafter: Tac., Ann.], XII, 54; Cf. R. Metzner, Die Prominenten im Neuen Testament. Ein prosopographischer Kommentar, Göttingen 2008, p. 498, annotation 755). Josephus' version and unity of power was followed by E. Schürer (The History of the Jewish People in the Age of Jesus Christ. (175 B.C.135 A.D.), revised edition by G. Vermes, F. Millar, M. Goodman, vol. 1, Edinburgh 1973, pp. 459-460). Another approach was adopted by M. Aberbach, who claims that the power was divided into southern (Cumanus) and northern (Felix) Judaea (see: M. Aberbach, The Conflicting Accounts of Josephus and Tacitus concerning Cumanus' and Felix' Terms of Office, 'The Jewish Quarterly Review' 1949, 40,1, pp. 1-14). The situation was evaluated similarly by Edith Mary Smallwood, who believes that Cumanus' competences were transferred onto Felix after the former had come into conflict with the Jews (see: E.M. Smallwood, The Jews Under Roman Rule from Pompey to Diocletian: A Study in Political Relations, Leiden 1981, pp. 266-267).

2 Fixing the last moment of his stay in the province is difficult as there is inconsistency between the written and numismatic sources. The first coins of Porcius Festus, the successor of Felix, are dated back to the fifth year of Nero's reign, i.e. 58/59 A.D. (see: A. Burnett, M. Amandry, P.P. Ripollès, Roman Provincial Coinage, vol. 1, From the Death of Caesar to the Death of Vitellius (44 B.C.-A.D. 69), London-Paris 1992, I 4972; Y. Meshorer, Ancient Jewish Coinage Volume II: Herod the Great Through Bar Cochba, New York 1982, pp. 181-183). This means that Felix must have fulfilled a function of procurator till 58, Festus from 58 to 60, and Lucceius Albinus from 60 to 64. This thesis is supported also by a statement by Josephus in Antiquitates Iudaicae, that Agrippa II changed the name of Paneas (Banias)/Caesarea Philippi to Neronias when Albinus was in office (see: Flavius Josephus, Antiquitates Judaicae, ed. B. Niese, in: Flavii Iosephi, Opera, vol. 1-4, Berlin 1885-1892 [hereinafter: Joseph., AJ], XX 9.4 (211). The epoch of Neronias was to have been started in 60/61 A.D., so Lucceius Albinus must have become a procurator of Judaea before, that is, already in 60 A.D. Therefore, Felix would have stayed in Judaea between 52 and 58 (see: N. Kokkinos, The Herodian Dynasty. Origins, Role in Society and Eclipse, Sheffield 1998, pp. 385-386).

3 Joseph., AJ, XX 8.5 (162-165).

4 Corpus Inscriptionum Latinarum, Berlin 1863- [hereinafter: CIL], XIV 2833; VI 11965. For more on Marcus Antonius Pallas, see: S.V. Oost, The Career of M. Antonius Pallas, 'American Journal of Philology' 1958, 79, pp. 113-139.

5 Suetonius, Lives of the Caesars, vol. 2, Claudius. Nero. Galba, Otho, and Vitellius. Vespasian. Titus, Domitian. Lives of Illustrious Men: Grammarians and Rhetoricians. Poets 
This article is aimed at the characterization of the aforementioned wives of Felix, especially of Drusilla of Mauretania, as well as the second of Felix's wives, the daughter of Herod Agrippa I. Particular attention shall be paid to the former as she evokes the interest of researchers due to her descent. Tacitus' view on the subject has been unfairly, as it may be concluded, questioned by the scientists.

According to Tacitus, Drusilla of Mauretania, the first wife of Felix, was a granddaughter of Cleopatra VII and Mark Antony ('Drusilla Cleopatrae et Antonii nepte in matrimonium accepta ${ }^{\prime}{ }^{6}$, hence her parents were Juba II the king of Mauretania ${ }^{7}$ - and Cleopatra Selene ${ }^{8}$. However, in 2001 Tacitus' opinion was challenged by Frederick E. Brenk and Filippo C. De Rossi, who claimed that Drusilla would have been not a granddaughter, instead must have been a great-granddaughter of Cleopatra VII ${ }^{9}$. The thesis of the Italian scholars met with acceptance of some researchers. It was hinged on arguments based on certain chronological complications. The scientists thought that it was not possible that Drusilla could have lived for at least seventy years ${ }^{10}$. They believed that Cleopatra Selene was born before 34 B.C., started her relationship with Juba around 20 B.C., and was dead by about 5 B.C. Thus, as it was calculated, Selene would have given birth to Drusilla between 19 and 9 B.C. According to the Italian scholars, this means that in 60 A.D., i.e. when Saint Paul was judged by Felix, Drusilla would have been at least seventy years old, or even eighty ${ }^{11}$. Frederick E. Brenk and Filippo C. De Rossi point this out as impossible. In their opinion, Felix could not have married a granddaughter, but a greatgranddaughter of Cleopatra VII and Mark Antony. Following this theory, one may suppose that Felix's wife was born between 1 and 20 A.D., which means that she would have been some twenty years younger than it was earlier asserted. The researchers have not proven, however, who in this

(Terence. Virgil. Horace. Tibullus. Persius. Lucan). Lives of Pliny the Elder and Passienus Crispus, transl. J.C. Rolfe, Cambridge 1914, Claudius, 28.

6 Tacitus, Histories, books 4-5, Annals, books 1-3, transl. C.H. Moore, J. Jackson, Cambridge 1931 [hereinafter: Tac., Hist.], V 9.

7 Prosopographia Imperii Romani Saeculi I, II, III, 1st edn. E. Klebs, H. Dessau (18971898); 2nd edn. E. Groag et al., Berlin-Leipzig 1933 - [hereinafter: PIR²], I 0065.

$8 \mathrm{PIR}^{2}, \mathrm{C} 1148$.

9 F.E. Brenk, F.C. De Rossi, The 'Notorious' Felix, Procurator of Judaea, and His Many Wives (Acts 23-24), 'Biblica' 2001, 82, 3, pp. 410-417. The researchers did not prove whose daughter would have been Drusilla, had she not been the granddaughter of Cleopatra VII.

${ }_{10}$ The thesis of Frederick E. Brenk and Filippo C. De Rossi was optimistically accepted by many scholars. See: e.g. C. Bennet, Drusilla Regina Source, 'Classical Quarterly' 2003, 53, 1, pp. 315-319; J. Yoder, Representatives of Roman Rule: Roman Provincial Governors in LukeActs, Berlin 2014, pp. 277-302.

11 Cf. F.E. Brenk, F.C. De Rossi, op. cit., p. 411. 
case is supposed to be the mother and father of Drusilla. The thesis itself abounds in other weak points.

As the sources say, Cleopatra Selene was born around 40 B.C. ${ }^{12}$, had a relationship with Juba between 25 and 20 B.C. ${ }^{13}$, and passed away before 18 A.D. ${ }^{14}$ Drusilla could have been born between 24 and 1 B.C. ${ }^{15}$, which means that Felix's wife could have been even eight years younger than Frederick E. Brenk and Filippo C. De Rossi thought. Moreover, both the

12 Plutarch, Lives, vol. 9, Demetrius and Antony. Pyrrhus and Gaius Marius, transl. B. Perrin, Cambridge 1920, Vita Marci Antonii, 36; cf. D.W. Roller, The World of Juba II and Kleopatra Selene, London 2004, p. 77.

13 According to Cassius Dio (Cassius Dio, Roman History, vol. 6, books 51-55, transl. E. Cary, H.B. Foster, Cambridge 1917 [hereinafter: Cass. Dio], 53.26.2), Juba would have been given a territory $\Gamma \alpha \iota \tau o v \lambda i \alpha \varsigma$ by Augustus during his ninth consulate (25 B.C.). This year is confirmed by Tacitus' data (Tac., Ann., 4, 5), who mentions Juba still in the ninth year of the reign of Tiberius, i.e. in 23 A.D., as well as by the coins presenting Juba as a king of Mauretania in the forty eighth year of his reign. In this case, Juba could have started his relationship with Cleopatra Selene in 25 B.C. This thesis is supported by Duane W. Roller, who states that Cleopatra Selene and Juba had acquired already their marriageable age (he would have been twenty-five years old, whereas she-fifteen), so they could have been wedded even before they left Rome. Thus, the first coin showing Cleopatra Selene and Juba, which is dated back to 20/19 B.C., would have been minted on the fifth anniversary of their wedding (D.W. Roller, op. cit., p. 86. The coins of Juba, see: J. Mazard, Corpus Nummorum Numidiae Mauretaniaeque, Paris 1955, pp. 71-126). For other suggestions regarding the year of their entering into marriage, see: J. Mazard, Un denier inédit de Juba II et Cléopâtre-Sélène, 'Schweizer Münzblätter' 1981, 31, pp. 1-2.

14 Duane W. Roller assumes that Cleopatra died before 5 B.C. Frederick E. Brenk and Filippo C. De Rossi share this opinion. The aforementioned date was fixed on the basis of the second marriage of Juba as well as of an epigram about Selene (Krinagoras 18 [The Greek Anthology, vol. 2, book 7, Sepulchral Epigrams, Book 8, The Epigrams of St. Gregory the Theologian, transl. W.R. Paton, Cambridge 1917, Palatine Anthology, 7.633]). It presents a lunar eclipse which is often associated with the death of Cleopatra Selene. It was visible from Mauretania and occurred in 9 and 5 B.C. and in 3, 7, 10, 11, 14 A.D. (https://eclipse. gsfc.nasa.gov/LEcat5/LE-0099-0000.html [accessed on: 15 V 2018]); https://eclipse.gsfc.nasa. gov/LEcat5/LE0001-0100.html [accessed on: 15 V 2018]). The scholars claim that Cleopatra died before 5 B.C., as it would have happened before the wedding of Juba and Glaphyra, which took place in 6 A.D. (for more on the subject, see: D.W. Roller, op. cit., pp. 249-251). It cannot be ruled out, however, that Cleopatra died about 11 A.D. This was the year when an eclipse of the moon occurred and when the issues of coins with the image of Cleopatra Selene started to appear. The last coin with the image of Cleopatra is dated at 17 A.D. The coins may have been embossed to commemorate the deceased Cleopatra or to inform about her renewed relationship with Juba, who could have come back to his first wife after his second wife - Glaphyra - had died. Then, Cleopatra would have passed away around 17 A.D.

${ }^{15}$ It has been assumed in the article that Cleopatra gave birth to Drusilla before she turned forty, which was nothing extraordinary. There were cases of women in antiquity who were fertile even up till they were fifty years old. For more on the subject, see: W. Scheidel, Demography, in: The Cambridge Economic History of the Greco-Roman World, eds. W. Scheidel, I. Morris, R. Saller, Cambridge 2007, pp. 66-67. 
scientists, claiming that Drusilla could not have been the daughter of Juba and Selene, point to her age at the time of Saint Paul's trial, that is, in 60 A.D. ${ }^{16}$ This statement seems to be groundless, however, as in the Acts of the Apostles Drusilla is mentioned as a Jewess ${ }^{17}$. This means that Luke the Evangelist recalls here the daughter of Agrippa I, i.e. the second wife of Felix, whose name was Drusilla as well, and not the granddaughter of Cleopatra VII and Antony. As it can be supposed, Drusilla of Mauretania could have died before the end of Felix's term of office in Judaea if she was not mentioned by the author of the Acts of the Apostles. She might have been absent already when Felix was acting as a procurator of Judaea. Eventually, he started his relationship with his second wife. Even if they had been together in their 50s, this would not deny the supposition that Drusilla could have been the granddaughter of Cleopatra VII. She would have been fifty-seventy years old ${ }^{18}$.

It is unknown when Felix was born, which seems particularly crucial for these reflections. The procurator of Judaea came into the world as a Greek slave ${ }^{19}$ and was liberated by Antonia Minor or the Emperor Claudius $^{20}$. Nevertheless, we lack the information when exactly it could have happened. Felix could have been of a similar age to Drusilla of Mauretania.

Taking into consideration Felix's weakness for aristocratic women - after all, he had three royal wives - it may be supposed that the possible difference of ten or twenty years between him and Drusilla was not a problem for the procurator. Hence, also the argument referring to the difference in age between the spouses is not convincing. Thanks to his involvement with aristocrat women, Felix could have gradually increased his social status.

16 The trial of Paul was conducted in the last year of Felix's acting in Judaea. If the coins connected with the succeeding governor Porcius Festus date actually at 59, Felix stayed in the province until 58 A.D. For more on the subject, see the footnote 2.

17 The Acts of the Apostles: The Greek Text with Introduction and Commentary, ed. F.F. Bruce, London 1952 [hereinafter: Acts], 24, 24.

${ }^{18}$ It is worth reminding that in Rome in the 1st c. A.D. people in their sixties and seventies were considered old. An age like that was reached by $30 \%$ of those who had survived to be five years old. For more on the subject, see: W. Suder, Kloto, Lachesis, Atropos. Studia społeczno-demograficzne i medyczne z historii starożytnego Rzymu, Wrocław 1994, p. 56.

19 Tac., Hist., V 9.

${ }^{20}$ Many studies have appeared on the subject of Felix' gentilicium and who was to free him. The view that Felix was a freedman of Antonia Minor was expressed by Emil Schürer (op. cit., pp. 460-461), E. Mary Smallwood (op. cit., p. 268, annotation 37), and Colin Hemer (The Name of Felix Again, 'Journal for the Study of the New Testament' 1987, 31, pp. 45-49). Contrary to this opinion were Frederick F. Bruce (The Full Name of the Procurator Felix, 'Journal for the Study of the New Testament' 1978, 1, p. 33-36) or Nikos Kokkinos (A Fresh Look at the gentilicium of Felix Procurator of Judaea, 'Latomus' 1990, 49, 1, pp. 126-141). 
As already noticed, Frederick E. Brenk and Filippo C. De Rossi did not define who would have been Drusilla's parents if she had been the greatgranddaughter of Cleopatra VII. Apart from Cleopatra Selene, Cleopatra VII and Mark Antony had two sons: Alexander Helios ${ }^{21}$ and Ptolemy Philadelphos ${ }^{22}$. Most probably, they both died before 25 B.C. ${ }^{23}$, so the kinship of Felix's wife with Cleopatra VII must have included Cleopatra Selene. The latter had the son Ptolemy of Mauretania ${ }^{24}$, which means that he must have been Drusilla's father if she had been Antony's great-granddaughter. Still, nothing is known about the unknown daughter of Ptolemy. The case of Cleopatra Selene seems different. Her daughter with Juba II is confirmed in an inscription. The name of Juba's daughter is not given there, however ${ }^{25}$.

The last inaccuracy pointed out by another researcher, Chris Bennett, was the name of Drusilla of Mauretania. The historian claims that it is groundless for Cleopatra Selene to have called her daughter this name because she had no such example among her ancestors, and surely she wanted to continue the tradition of the family names ${ }^{26}$. It is quite the opposite as regards the great-granddaughter of Cleopatra VII, who would have been born after the death of Livia Drusilla or Julia Drusilla. One should remember that this name was well known at this time ${ }^{27}$. It seems, however, that there is more to support the thesis about the name being used by Cleopatra Selene than by her descendants. After all, Cleopatra was brought up by Augustus' sister, Octavia the Younger $^{28}$, so she could have met Livia Drusilla, Augustus' wife, and then named her own daughter in honor of the former. Furthermore, Juba and Cleopatra Selene were brought up with Drusus the Elder, who died in 9 B.C. ${ }^{29}$ Thus, it can be assumed that the couple could have named their daughter Drusilla to commemorate their friend ${ }^{30}$. Besides, Cleopatra left her family name to her first-born child as she named her son Ptolemy.

In light of the above remarks, it seems obvious that Drusilla of Mauretania could have been the granddaughter, not the great-granddaughter, of

21 PIR ${ }^{2}, \mathrm{~A} 0495$.

$22 \mathrm{PIR}^{2}, \mathrm{P} 1033$.

${ }^{23}$ Cass. Dio, 51.15.6; D.W. Roller, op. cit., p. 83.

24 D.W. Roller, op. cit., pp. 252-256.

25 Inscriptiones Graecae, vol. II et III, Inscriptiones Atticae Euclidis anno posteriores. Editio altera, ed. J. Kirchner 1913-1940, Reimer (1913-1916), De Gruyter-Berlin, II², 3439.

${ }^{26}$ Cf.: C. Bennett, op. cit., p. 316; D.W. Roller, op. cit., p. 251.

27 The second wife of Felix is an example that the name Drusilla used to be given frequently after the death of Livia and Julia.

28 D.W. Roller, op. cit, pp. 82-85.

${ }^{29}$ Ibidem, p. 252.

30 Then, Drusilla would have been born after 9 B.C. 
Cleopatra VII and Mark Antony, so there is no reason to discredit the historical record by Tacitus as regards this issue.

The second wife of Felix was Drusilla, the daughter of Agrippa I and the sister to Drusus, Herod Agrippa II, Berenice III and Mariamme VI ${ }^{31}$. Herod Agrippa I betrothed her to Epiphanes ${ }^{32}$, son of Antiochus IV, king of Commagene, but on condition that the groom would convert to Judaism ${ }^{33}$. The future husband opposed this demand and the engagement fell apart. Around 50 A.D. Drusilla married Azizus, king of Emesa ${ }^{34}$; however, she left him soon for Felix ${ }^{35}$. Some scientists believe that this daughter of Agrippa I started her relationship with Felix only after the king of Emesa had died, but it seems much more likely that it happened before 54, as Josephus primarily describes the meeting of Felix with Drusilla. The governor of Judaea was supposed to have fallen in love with the queen at first sight ${ }^{36}$. No earlier does the Jewish historian pronounce the death of her first husband.

The relationship of Drusilla and Felix must have been bolstered by Herod Agrippa II, for whom it was an element of his politics, as he cared about proper relations with the Roman magistrate ${ }^{37}$. Drusilla accompanied Felix at least till the end of his stay in Judaea, because she is mentioned during the trial of Saint Paul ${ }^{38}$. Josephus informs that the couple had a son, Agrippa III ${ }^{39}$, who died along with his wife in the eruption of Mount Vesuvius in $79^{40}$. Some researchers claim that Felix had also a daughter ${ }^{41}$.

Suetonius records that Felix had also a third wife. Little is known, however, as to when he would have formed his relationship with her.

31 P. Richardson, Herod: King of the Jews and Friend of the Romans, Columbia 1996, p. 50.

32 Joseph., AJ, XIX 9.1 (355).

33 Joseph., AJ, XX 7.1 (139).

34 Ibidem.

35 Acc. to F.E. Brenk and F.C. De Rossi, Drusilla was supposed to have had a relationship with Felix only after the death of Azizus, that is, in 54/55 A.D. (F.E. Brenk, F.C. De Rossi, op. cit., pp. 412-413); similarly J. Wilker, Für Rom und Jerusalem. Die herodianische Dynastie im 1. Jahrhundert n. Chr., Frankfurt am Main 2007, p. 60. Josephus, however, firstly described the relationship of Felix and Drusilla, and not until some lines further on did he mention Azizus' death, see: Joseph., AJ, XX 8.4 (158).

36 Joseph., AJ, XX 7.2 (142).

37 For more on the politics of Herod Agrippa II, see: J. Wilker, op. cit., pp. 49-67.

38 Acts, 24, 24.

39 Similarly as in the case of Felix, there are two theories regarding the gentilicium of Agrippa III. Depending on the assumed version of the gentilicium of the governor of Judaea, Agrippa III is referred to as Tiberius Claudius or Marcus Antonius.

${ }^{40}$ Joseph., AJ, XX 7.2. (143-144).

41 If the inscription CIL, V 34 refers to the great-grandson of Felix, the latter could have had also a daughter. For more on the subject, see: C. Hemer, op. cit., pp. 47-48. It cannot be unambiguously stated that the inscription concerns the procurator of Judaea, as Antonius Felix was mentioned there but marginally. It may have been related to another Felix. 
It may have happened after he had seized his official stay in Judaea. The only mention regarding the last wife of Felix relates to her royal descent.

Summing up the above considerations, one may state that Felix, the Roman procurator of Judaea Province, had three wives. The first was the daughter of Cleopatra Selene and Juba II, hence the granddaughter of Cleopatra VII and Mark Antony. Drusilla was born between 24 and 1 B.C. She must have owed her name to the friendship of her parents with Drusus or to the mother of Augustus - Livia Drusilla. Nothing can be said about how long was the relationship between Drusilla and Felix, nor when she died. It seems, however, that the deliberations by Frederick E. Brenk and Filippo C. De Rossi were wrong, whereas the record of Tacitus right.

The second wife of the Judean procurator was Drusilla, the daughter of Herod Agrippa I, who was married by Felix before 54, that is, before her husband Azizus had died. The couple could have had a son and perhaps a daughter too. It is known that Drusilla was with Felix at least till the end of his acting in Judaea. The last of Felix's wives remains anonymous.

(translated by LINGUA LAB)

\section{REFERENCES}

\section{Printed sources}

Dio Cassius, Roman History, vol. 6, books 51-55, transl. E. Cary, H.B. Foster, Cambridge 1917. Corpus Inscriptionum Latinarum, Berlin 1863-

Die Annalen des Tacitus, vol. 2, books 11-16, ed. A.A. Draeger, Leipzig 1869.

Flavius Josephus, Antiquitates Judaicae, ed. B. Niese, in: Flavii Iosephi, Opera, vol. 1-4, Berlin 1885-1892.

Inscriptiones Graecae, vol. II et III, Inscriptiones Atticae Euclidis anno posteriores. Editio altera, ed. J. Kirchner 1913-1940, Reimer (1913-1916), De Gruyter-Berlin.

Plutarch, Lives, vol. 9, Demetrius and Antony. Pyrrhus and Gaius Marius, transl. B. Perrin, Cambridge 1920.

Prosopographia Imperii Romani Saeculi I, II, III, 1st edn. E. Klebs, H. Dessau (1897-1898); 2nd edn. E. Groag et al., Berlin-Leipzig 1933-

Suetonius, Lives of the Caesars, vol. 2, Claudius. Nero. Galba, Otho, and Vitellius. Vespasian. Titus, Domitian. Lives of Illustrious Men: Grammarians and Rhetoricians. Poets (Terence. Virgil. Horace. Tibullus. Persius. Lucan). Lives of Pliny the Elder and Passienus Crispus, transl. J.C. Rolfe, Cambridge 1914.

Tacitus, Histories, books 4-5, Annals, books 1-3, transl. C.H. Moore, J. Jackson, Cambridge 1931.

The Acts of the Apostles: The Greek Text with Introduction and Commentary, ed. F.F. Bruce, London 1952.

The Greek Anthology, vol. 2, book 7, Sepulchral Epigrams, book 8, The Epigrams of St. Gregory the Theologian, transl. W.R. Paton, Cambridge 1917. 


\section{Studies}

Aberbach M., The Conflicting Accounts of Josephus and Tacitus Concerning Cumanus' and Felix' Terms of Office, 'The Jewish Quarterly Review' 1949, 40, 1.

Bennet C., Drusilla Regina Source, 'Classical Quarterly' 2003, 53, 1.

Brenk F.E., De Rossi F.C., The 'Notorious' Felix, Procurator of Judaea, and His Many Wives (Acts 23-24), 'Biblica' 2001, 82, 3.

Bruce F.F., The Full Name of the Procurator Felix, 'Journal for the Study of the New Testament' 1978, 1.

Burnett A., Amandry M., Ripollès P.P., Roman Provincial Coinage, vol. 1, From the Death of Caesar to the Death of Vitellius (44 B.C.-A.D. 69), London-Paris 1992.

Hemer C., The Name of Felix Again, 'Journal for the Study of the New Testament' 1987, 31.

Kokkinos N., A Fresh Look at the gentilicium of Felix Procurator of Judaea, 'Latomus' 1990, $49,1$.

Kokkinos N., The Herodian Dynasty. Origins, Role in Society and Eclipse, Sheffield 1998.

Mazard J., Corpus Nummorum Numidiae Mauretaniaeque, Paris 1955.

Mazard J., Un denier inédit de Juba II et Cléopâtre-Sélène, 'Schweizer Münzblätter' 1981, 31.

Meshorer Y., Ancient Jewish Coinage Volume II: Herod the Great Through Bar Cochba, New York 1982.

Metzner R., Die Prominenten im Neuen Testament. Ein prosopographischer Kommentar, Göttingen 2008.

Oost S.V., The Career of M. Antonius Pallas, 'American Journal of Philology' 1958, 79.

Richardson P., Herod: King of the Jews and Friend of the Romans, Columbia 1996.

Roller D.W., The World of Juba II and Kleopatra Selene, London 2004.

Scheidel W., Demography, in: The Cambridge Economic History of the Greco-Roman World, eds. W. Scheidel, I. Morris, R. Saller, Cambridge 2007.

Schürer E., The History of the Jewish People in the Age of Jesus Christ (175 B.C. - 135 A.D.), revised edition by G. Vermes, F. Millar, M. Goodman, vol. 1, Edinburgh 1973.

Smallwood E.M., The Jews Under Roman Rule from Pompey to Diocletian: A Study in Political Relations, Leiden 1981.

Suder W., Kloto, Lachesis, Atropos. Studia społeczno-demograficzne i medyczne z historii starożytnego Rzymu, Wrocław 1994.

Wilker J., Für Rom und Jerusalem. Die herodianische Dynastie im 1. Jahrhundert n. Chr., Frankfurt am Main 2007.

Yoder J., Representatives of Roman Rule: Roman Provincial Governors in Luke-Acts, Berlin 2014.

\section{Internet sources}

https://eclipse.gsfc.nasa.gov/LEcat5/LE-0099-0000.html [accessed on: 15 V 2018].

https://eclipse.gsfc.nasa.gov/LEcat5/LE0001-0100.html [accessed on: 15 V 2018].

\section{STRESZCZENIE}

W artykule podjęta została próba przedstawienia żon Feliksa - prokuratora Judei w latach 52-58/60 po Chr. Namiestnik miał związać się z trzema kobietami, z których dwie znane są bliżej. Autor podejmuje się rozwiązania problemu pokrewieństwa pierwszej z nich - Druzylli Mauretańskiej z Kleopatrą VII, o czym wspomina Tacyt. Niektórzy badacze podważyli jednak stwierdzenie historyka rzymskiego, jakoby Druzylla miała być wnuczką królowej egipskiej. Zostało to pozytywnie przyjęte przez większą część historyków i powtarzane w kolejnych pracach, w których pojawia się Druzylla Mauretańska. Ponowna analiza problemu wykazuje, że Tacyt miał jednak rację i Druzylla była wnuczką 
Kleopatry. W drugiej części artykułu zaprezentowana została druga żona Feliksa, która była córką Agryppy I i miała związać się z prokuratorem Judei podczas jego pobytu w prowincji.

Słowa kluczowe: Judea, Żydzi, rzymskie prowincje w I w. po Chr., namiestnicy rzymscy, administracja rzymska, prefekci i prokuratorzy w Judei

\section{ABOUT THE AUTHOR}

Roman Deiksler - PhD student of ancient history at the Faculty of History of the Adam Mickiewicz University in Poznań. His research interests include Ancient Israel, Judea in the 1st century AD, Jews in Judea in 6-135 AD, Christianity in the Roman Empire. 